\title{
Physicochemical Quality of Honey Samples Collected from Chena District, Southwestern Ethiopia
}

\author{
Dekamo Fiseha Lomiso $^{1,}$, , Gezahegn Nigussie ${ }^{3}$, Engida Dessalegn ${ }^{2}$ \\ ${ }^{1}$ Southern Agricultural Research Institute, Bonga Agricultural Research Center, Bonga, Ethiopia \\ ${ }^{2}$ Awassa College of Teacher Education, Hawassa, Ethiopia \\ ${ }^{3}$ Department of Food Science and Post-harvest Technology, Hawassa University, Hawassa, Ethiopia
}

Email address:

dekamofiseha13@gmail.com(D. F. Lomiso),gezahegn41@yahoo.com (G. Nigussie), engidae@yahoo.com (E. Dessalegn)

${ }^{*}$ Corresponding author

\section{To cite this article:}

Dekamo Fiseha Lomiso, Gezahegn Nigussie, Engida Dessalegn. Physicochemical Quality of Honey Samples Collected from Chena District, Southwestern Ethiopia. Journal of Food and Nutrition Sciences. Vol. 9, No. 5, 2021, pp. 117-123. doi: 10.11648/j.jfns.20210905.12

Received: August 11, 2021; Accepted: August 26, 2021; Published: September 27, 2021

\begin{abstract}
The objective of this study was to determine physicochemical properties (color, moisture, ash, $\mathrm{pH}$, free acidity, HMF, reducing sugars, sucrose and electrical conductivity) of honey produced in Chena district, Southwestern Ethiopia. Nine (9) honey samples each of 0.5 to $1 \mathrm{~kg}$ were obtained from Chena district. Moisture and ash content were determined by AOAC method. $\mathrm{pH}$ was determined by digital $\mathrm{pH}$ meter. HMF and honey color were determined by using spectrophotometer. The free acidity was quantified by titration method. Total reducing sugar and sucrose contents were determined by Lane and Enyon method. There was significant variation $(\mathrm{p}<0.05)$ observed between honey samples. The result revealed that $\mathrm{S}_{2}$ and $\mathrm{S}_{6}$ honey samples contained the highest ash $(0.3 \pm 0.02$ and $0.3 \pm 0.04 \mathrm{~g} / 100 \mathrm{~g}$, respectively), free acidity $(39 \pm 1.4 \mathrm{and} 41 \pm 1.4 \mathrm{meq} / \mathrm{kg}$, respectively) and electrical conductivity $(0.68 \pm 0.08$ and $0.67 \pm 0.04 \mathrm{mS} / \mathrm{cm}$, respectively) than other honey samples. The honey samples $\mathrm{S}_{7}$ and $\mathrm{S}_{8}$ had highest moisture content $(22.5 \pm 1.4$ and $21.2 \pm 1.7 \mathrm{~g} / 100 \mathrm{~g}$, respectively) and honey color (124 \pm 0.5 and $123 \pm 2.1 \mathrm{~mm}$ Pfund scale, respectively) than other honey samples. The honey sample $\mathrm{S}_{5}(4 \pm 0.2), \mathrm{S}_{6}(4 \pm 0.2)$, and $\mathrm{S}_{9}$ $(4.2 \pm 0.4)$ had highest $\mathrm{pH}$ value. In addition, the result showed that $\mathrm{S}_{9}$ contained highest $\mathrm{HMF}$ content $(17.1 \pm 2 \mathrm{mg} / \mathrm{kg})$. Furthermore, honey sample $S_{1}(69.7 \pm 1 \mathrm{~g} / 100 \mathrm{~g})$ and $\mathrm{S}_{4}(70.2 \pm 1)$ contained the highest total reducing sugar. Finally, the result showed that honey sample $\mathrm{S}_{8}$ had highest sucrose content $(5.17 \pm 0.8 \mathrm{~g} / 100 \mathrm{~g})$. Results obtained in this study, indicated that tested honey samples produced in Chena district are good for national as well as international market. More research should be conducted on the storage effect of honey to evaluate its safety for human consumption.
\end{abstract}

Keywords: Physicochemical Properties, Quality, HMF, Honey, Chena

\section{Introduction}

Honey is the natural sweet substance produced by honeybees (Apis mellifera L.) from the nectar of blossoms or from secretions of living parts of plants or excretions of plant-sucking insects on the living parts of plants, which the bees collect, transform by combining with specific substances of their own, deposit, dehydrate, store and leave in honeycombs to ripen and mature [1]. It is a natural food produced by bees from nectar or secretion of flowers. Honey has a content of $80-85 \%$ carbohydrates (mainly glucose and fructose), $15-17 \%$ water, $0.3 \%$ proteins, $0.2 \%$ ashes, and minor quantities of vitamins as well as other components in low levels of concentration [2, 3]. The physicochemical properties vary by regional locations, climatic conditions, environmental conditions, soil type and treatment of beekeepers [4]. The precise physicochemical properties of natural honeys also differ according to the plant species on which the bees forage and also climatic conditions and vegetation which are important factors that can affect the various properties of honey [5].

In Ethiopia, more than one million households are estimated to keep bees using traditional, intermediate and modern hives [5]. The annual honey production of Ethiopia is estimated to be 45,300 metric tons which makes the country to rank first honey producing country in Africa and ninth in the world [6]. Honey is produced commercial purpose by 
almost all beekeepers in Ethiopia; they keep bees for the purpose of income generation. For household consumption, they use less than $10 \%$ of their total harvest at home mainly for medicinal and cultural ceremonies, and the remaining $90 \%$ is available for sale. The largest portion of the marketed honey estimated $70 \%$ goes to the production of local beverage called 'tej' and 'birz', while the remained small portion is used as a table honey [7].

Despite of having the highest bee density and being the leading honey producer as well as one of the largest beeswax exporting countries in Africa, the share of the subsector in the GDP has never been matched with the huge numbers of honey bee colonies and the country's potentiality for beekeeping. Productivity has always been low, leading to low utilization of modern and transitional hive products domestically, and relatively low export earnings [7]. Thus, the beekeepers in particular and the country in general are not benefiting from the subsector [8].

Kaffa Zone has great potential for beekeeping activities due to the presence of diversified types of bee floras which used as pollen and nectar source for bees and suitable environmental conditions for bee colony and the production of honey [9]. However, due to the traditional method of beekeeping and handling practices used in the area the resource is underutilized. The honey obtained from a beekeeping sector of the area is still low as compared to the available potential of the country. To our knowledge, the scientific data on the physicochemical quality of honey from Chena district is very limited. The need to investigate the physicochemical quality characteristics of honey produced in the Chena district is thus, necessary to provide basis for any intervention that will improve the honey industry. Moreover, in order to increase income of beekeepers and marketability of honey produced in the study area, it is important to determine the physicochemical properties of the honey vis-àvis national and international standards set for honey.

\section{Materials and Methods}

\subsection{Description of the Study Area}

The study was conducted in Southern Nations, Nationalities and Peoples Regional State of Ethiopia, Kaffa zone, Chena district (Figure 1). Chena is located from $510 \mathrm{~km}$ from Addis Ababa, capital city of Ethiopia and $738 \mathrm{~km}$ from Hawassa, the capital of the SNNPRS. The altitude of the district ranges from 1500 to 3000 m.a.s.l. The area has a varying topography composed of steep, mountains, and plateau. The area is located at $07^{\circ} 18^{\prime} 48^{\prime \prime} \mathrm{N}$ latitude and $036^{\circ} 16^{\prime} 25^{\prime \prime}$ longitude. The total area of Chena district is estimated to be $901.92 \mathrm{~km}^{2}$ that is endowed with natural tropical rain forests with suitable climates that favor high honeybee population density, and forest beekeeping is widely practiced.

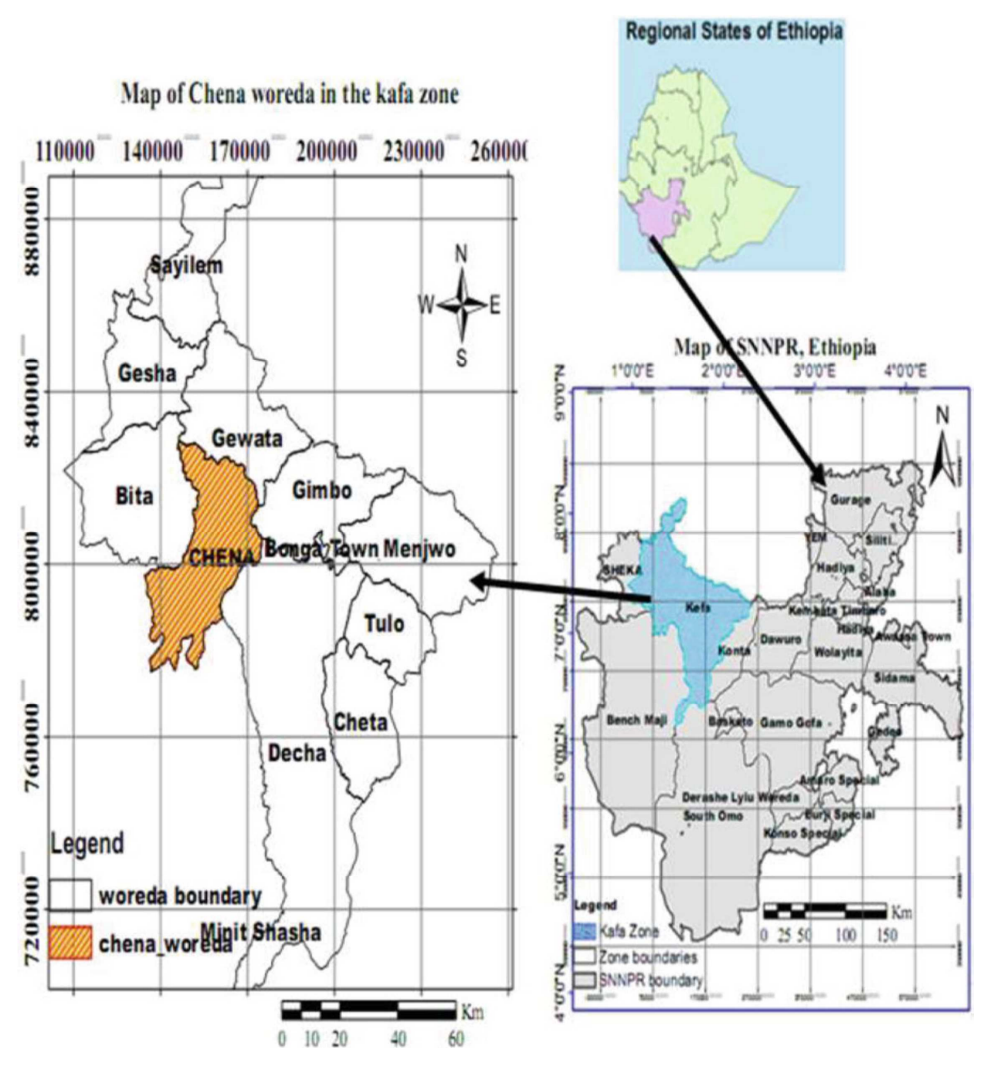

Figure 1. Map of the study area.

\subsection{Collection of Honey Samples}

To evaluate the physicochemical quality of honey, 9 honey samples $0.5-1 \mathrm{~kg}$ each were randomly collected from beekeepers. The collected honey samples were homogenized 
by stirring thoroughly to prepare representative sample and labeled. All the honey samples were stored at ambient temperature, in sample plastic-bottles with tight-fitting lids, during the period of analytical investigation. The laboratory analysis was done at Hawassa University Food Chemistry and Microbiology and Chemistry laboratory.

\subsection{Determination of Physicochemical Properties}

\subsubsection{Honey Color}

Honey samples were diluted in water $(1: 1 ; \mathrm{w} / \mathrm{v})$, and the color was determined by Spectro photometric (Mark) measurement of the absorbance of a $50 \%$ honey solution $(\mathrm{w} / \mathrm{v})$ at $635 \mathrm{~nm}$. Results were calculated $(P f u n d=-38.70$ $+371.39 \times A b s)$ and expressed in millimeters [10].

\subsection{2. $\mathrm{pH}$}

A pH meter (Model: Hanna Instruments lab HI 98127, Mauritius) was used to measure the $\mathrm{pH}$ of honey. $10 \mathrm{~g}$ of duplicate honey samples were dissolved in $75 \mathrm{~mL}$ of distilled water in $250 \mathrm{~mL}$ beaker and stirred with the magnetic stirrer [10]. Then the $\mathrm{pH}$ was measured with digital $\mathrm{pH}$ meter, calibrated at $\mathrm{pH} 4.0$ and 7.0.

\subsubsection{Free Acid Value}

The acidity was determined by following the procedure of Codex Alimentarius Commission Standards [11]. $10 \mathrm{~g}$ of the duplicate samples were weighed and mixed with about 75 $\mathrm{mL}$ distilled water. Samples were titrated against $(0.1 \mathrm{M})$ sodium hydroxide solution using phenolphthalein indicator the end point was determined by pink color that persisted for seconds. The results, expressed in meq/Kg honey, were calculated as follows:

$$
\text { Acidity }(\mathrm{meq} / \mathrm{Kg})=\frac{\text { volume of } 0.1 \mathrm{MNaOH} \text { consumed }}{\mathrm{Kg} \text { of honey sample }} \mathrm{X} 10
$$

Where: 10 indicates the dilution factor of honey sample during analysis.

\subsubsection{Moisture Content}

Moisture content of each honey sample was determined according to AOAC [12] using oven. $5 \mathrm{~g}$ of the sample was placed in a pre-weighed aluminum dish. Then sample was dried to constant weight in an oven at $105^{\circ} \mathrm{C}$ for $4 \mathrm{~h}$.

$$
\text { Moisture content }=\frac{\mathrm{W} 1-\mathrm{W} 2}{\mathrm{~W} 1-\mathrm{W} 0} \times 100
$$

Where: W0 $=$ Weight of aluminum dish $(\mathrm{g})$; W1 $=$ Weight of the fresh sample + dish $(\mathrm{g})$ and $\mathrm{W} 2=$ Weight of the dried sample $+\operatorname{dish}(\mathrm{g})$.

\subsubsection{Ash Content}

The ash content was determined according to AOAC [12] using muffle furnace. $2 \mathrm{~g}$ of honey sample was weighed accurately in to a pre-weighed dish, and gently heated in a muffle furnace until the samples became black and dry. The sample was ignited at $550^{\circ} \mathrm{C}$ to constant weight. Percent ash in $\mathrm{g} / 100 \mathrm{~g}$ honey was calculated using the following formula, following the procedure of Codex Alimentarius Commission
Standards [11]. The ash was expressed as percentage using the Equation:

$$
\% \text { Ash }=\frac{\mathrm{W} 1-\mathrm{W} 2}{\mathrm{~W} 0} \times 100
$$

Where; $\mathrm{W}_{0}=$ Weight of honey taken; $\mathrm{W}_{1}=$ Weight of dish + ash; $\mathrm{W}_{2}=$ Weight of dish.

\subsubsection{Hydroxyl Methyl Furfural (HMF)}

The hydroxyl methyl furfural (HMF) content was determined by the method of Bogdanov et al. [10] based on the determination of UV absorbance of HMF at $284 \mathrm{~nm}$. In order to avoid the interference of other components at this wavelength, the difference between the absorbance of a clear aqueous honey solution and the same solution after addition of bisulphite was determined. The HMF content was calculated after subtraction of the background absorbance at $336 \mathrm{~nm}$. Spectrophotometer operating in a wavelength range including $284 \mathrm{~nm}$ and $336 \mathrm{~nm}$ was used.

$5 \mathrm{~g}$ of honey sample was weighed in small beaker and transfer with total of $25 \mathrm{~mL}$ distilled water to $50 \mathrm{~mL}$ volumetric flask. Then $0.5 \mathrm{~mL}$ of Carrez solution I (potassium hexacyanoferrate) was mixed with $0.5 \mathrm{~mL}$ of Carrez solution II (Zinc acetate and sodium bisulphate solution) and diluted to volume with distilled water and drop of alcohol was added to suppress foam. It was filtered through filter paper and the first $10 \mathrm{~mL}$ filtrate was discarded. $5 \mathrm{~mL}$ filtrate was pipetted into each of two $18 \mathrm{x}$ $150 \mathrm{~mm}$ test tubes. $5 \mathrm{~mL}$ of sample was pipetted out in two test tubes and $5 \mathrm{~mL}$ of water was added to the one test tube and mixed well. $5 \mathrm{~mL}$ of $0.2 \%$ sodium bisulphate solution was added to the second test tube and mixed well by using Vortex mixer for reference solution. The absorbance of the sample solution against the reference solution at $284 \mathrm{~nm}$ and $336 \mathrm{~nm}$ in $10 \mathrm{~mm}$ quartz cells within one hour was determined. When the absorbance at $284 \mathrm{~nm}$ exceeds a value of 0.6 , the sample solution diluted with water and the reference solution with sodium bisulphite solution in order to obtain a sample absorbance low enough for accuracy following the procedure of Codex Alimentarius Commission Standards (2001). When dilution is necessary, the amount of needed solution was added using dilution formula.

$$
\mathrm{D}=\frac{\text { Final Volume of Solution }}{10}
$$

Calculation and expression of result, $\mathrm{HMF}$ in $\mathrm{mg} / \mathrm{kg}=$ $\left(\mathrm{Abs}_{284}-\mathrm{Abs}_{336}\right) \times 149.7 \times 5 \times \mathrm{D} / \mathrm{W}$.

Where; $\mathrm{Abs}_{284}=$ absorbance at $284 \mathrm{~nm}: \mathrm{Abs}_{336}=$ absorbance at $336 \mathrm{~nm} ; 126=$ molecular weight of HMF; $16830=$ molar absorptivity $\varepsilon$ of HMF at $\lambda=284 \mathrm{~nm} ; \mathrm{D}=$ Dilution factor, if dilution necessary; $\mathrm{W}=$ Mass of honey sample $(\mathrm{g}) ; 1000=$ Conversion of $\mathrm{mg}$ into $\mathrm{g} ; 10=$ conversion of 5 into $50 \mathrm{~mL} ; 1000=$ Conversion of $\mathrm{g}$ of honey into $\mathrm{kg} ; 5$ $=$ Theoretical nominal sample weight.

Each honey sample was measured twice and the average values were recorded. 


\subsubsection{Sugar Content}

\section{(i). Total Reducing Sugar Content Before Inversion}

Representative quantity of $25 \mathrm{~g} \quad\left(\mathrm{~W}_{1}\right)$ of the homogeneous honey sample was dissolved in distilled water and diluted to $200 \mathrm{~mL}$ in a volumetric flask (honey solution). Then $50 \mathrm{~mL}$ of this honey solution was diluted to $100 \mathrm{~mL}$ using distilled water (diluted honey solution). Fifty $\mathrm{mL}$ of diluted honey solution was taken in the burette. $5 \mathrm{~mL}$ Fehling's solution A was pipetted into 250 $\mathrm{mL}$ Erlenmeyer flask and $5 \mathrm{~mL}$ Fehling's solution B was added. Approximately 7 to $8 \mathrm{~mL}$ of distilled water was added and heated until it starts boiling. $1 \mathrm{~mL}$ of $0.2 \%$ of methylene blue indicator was added and titration was completed during boiling only. The change in the color of the solution from blue to brick- red was taken as the end point of the reaction. The percentage of total reducing sugar before inversion was calculated by the following formula as developed by Lane and Eynon [13].

$$
\mathrm{C}=\left(25 / \mathrm{W}_{1}\right) \times\left(1000 / \mathrm{Y}_{2}\right)
$$

Where: $\mathrm{C}=\mathrm{g}$ total reduced sugar per $100 \mathrm{~g}$ honey

$\mathrm{W} 1=$ weight $(\mathrm{g})$ of honey sample

$\mathrm{Y} 2=$ volumes $(\mathrm{mL})$ of diluted honey solution consumed

\section{(ii). Total Reducing Sugar Content After Inversion}

$50 \mathrm{~mL}$ of honey solution, from the solution prepared for total reducing sugar before inversion was placed in a graduated flask, together with $25 \mathrm{~mL}$ distilled water, and heated to $65^{\circ} \mathrm{C}$ over a boiling water bath. The flask was then removed from the heated bath and $10 \mathrm{~mL}$ of hydrochloric acid was added. The solution was allowed to cool naturally for 15 minutes, and then brought to $20^{\circ} \mathrm{C}$ and neutralized with sodium hydroxide, using litmus paper as indicator, cooled again, and the volume adjusted to $100 \mathrm{~mL}$ (diluted honey solution). Then $5 \mathrm{~mL}$ of Fehling A, $5 \mathrm{~mL}$ of Fehling B and $7-8 \mathrm{~mL}$ of distilled water was taken in a $250 \mathrm{~mL}$ conical flask and heated till it starts boiling. After boiling, $1 \mathrm{~mL}$ of $0.2 \%$ of methylene blue indicator was added to the flask. The titration was completed while the solution is boiling. The end point of the reaction was recorded as the blue color changed to brick-red color. The percentage of total reducing sugar was calculated by the following formula and following the procedure of Codex Alimentarius Commission Standards [11].

$$
\mathrm{C}=\left(25 / \mathrm{W}_{1}\right) \times\left(1000 / \mathrm{Y}_{2}\right)
$$

Where: $\mathrm{C}=\mathrm{g}$ total sugar per $100 \mathrm{~g}$ honey; $\mathrm{W} 1=$ weight $(\mathrm{g})$ of honey sample: $\mathrm{Y}_{2}=$ volumes $(\mathrm{mL})$ of diluted honey solution consumed.

\section{Results and Discussion}

\subsection{Physicochemical Properties of Honey}

\subsubsection{Sucrose Content}

The percentage of sucrose was calculated as follows:

Sucrose content $=$ (total sugar content - total reducing sugar content) $\mathrm{x} 0.95$. The result was expressed as $\mathrm{g}$ apparent sucrose per $100 \mathrm{~g}$ honey, following the procedure of Codex Alimentarius Commission Standards [11].

\subsubsection{Electrical Conductivity}

Conductivity meter (Model: Hanna Instruments lab HI 8733, Mauritius) was used to determine electrical conductivity of the sample. $20 \mathrm{~g}$ of honey (on dry matter basis) was dissolved in distilled water and transferred to a $100 \mathrm{~mL}$ volumetric flask, and made up to volume with distilled water. $40 \mathrm{~mL}$ of this solution was poured into a beaker and placed in thermo stated water bath at $20^{\circ} \mathrm{C}$. An electrical conductivity measurement was obtained with a low range conductivity meter with a cell constant of 1.03 . The conductivity cell was thereafter be immersed in the sample solution and the conductance in $\mathrm{mS}$ read after temperature equilibrium had been reached. Electrical conductivity was calculated using the formula following the procedure of Codex Alimentarius Commission Standards [11].

$$
\mathrm{SH}=\mathrm{K} . \mathrm{G}
$$

Where; $\mathrm{SH}=$ electrical conductivity of the honey solution in $\mathrm{mS} . \mathrm{cm}^{-1} ; \mathrm{K}=$ cell constant in $\mathrm{cm}^{-1} ; \mathrm{G}=$ conductance in $\mathrm{mS}$.

\subsection{Statistical Analysis}

Physicochemical properties were performed in duplicate and analyzed by SAS software version 9.0 and expressed as mean standard deviation $( \pm)$. The mean values of honey samples were compared by using least significant difference (LSD), whenever one way ANOVA showed statistically

\begin{tabular}{|c|c|c|c|c|c|c|c|c|c|}
\hline \multicolumn{10}{|c|}{ Sample Parameter $($ Mean \pm SD) } \\
\hline & Color (mm Pfund) & Moisture (g/100g) & Ash (g/100g) & FA $\left(\mathrm{meqkg}^{-1}\right)$ & pH & HMF (mg/kg) & TRS & Sucrose $(\mathrm{g} / \mathbf{1 0 0 g})$ & EC $(\mathrm{mS} / \mathrm{cm})$ \\
\hline S1 & $69.2 \pm 0.4^{\mathrm{e}}$ & $17 \pm 0.7^{\mathrm{c}}$ & $0.2 \pm 0.02^{\mathrm{b}}$ & $21 \pm 1.4^{\mathrm{f}}$ & $3.7 \pm 0.04^{b}$ & $2.3 \pm 0.9^{\mathrm{e}}$ & $69.7 \pm 1.0^{\mathrm{a}}$ & $3.1 \pm 1.6^{\mathrm{cd}}$ & $0.48 \pm 0.04^{b}$ \\
\hline $\mathrm{S} 2$ & $91.3 \pm 0.2^{\mathrm{d}}$ & $19.5 \pm 0.7^{b}$ & $0.3 \pm 0.04^{\mathrm{a}}$ & $39 \pm 1.4^{\mathrm{a}}$ & $3.7 \pm 0.1^{\mathrm{b}}$ & $2.5 \pm 0.6^{\mathrm{e}}$ & $68 \pm 0.6^{\mathrm{ab}}$ & $4.73 \pm 0.8^{b}$ & $0.68 \pm 0.08^{\mathrm{a}}$ \\
\hline S3 & $104 \pm 5.2^{\mathrm{c}}$ & $19.7 \pm 1.0^{\mathrm{b}}$ & $0.2 \pm 0.04^{\mathrm{b}}$ & $28 \pm 2.8^{\mathrm{d}}$ & $3.6 \pm 0.07^{b}$ & $1.8 \pm 0.2^{\mathrm{e}}$ & $69 \pm 1.4^{\mathrm{a}}$ & $2.84 \pm 0.8^{\mathrm{d}}$ & $0.5 \pm 0.08^{b}$ \\
\hline S4 & $99 \pm 2.1^{\mathrm{cd}}$ & $17.3 \pm 1.0^{\mathrm{c}}$ & $0.14 \pm 0.03^{\mathrm{d}}$ & $25 \pm 2.8^{\mathrm{e}}$ & $3.7 \pm 0.2^{\mathrm{b}}$ & $3.3 \pm 1.6^{\mathrm{d}}$ & $70.2 \pm 1.0^{\mathrm{a}}$ & $3.2 \pm 0.45^{\mathrm{cd}}$ & $0.4 \pm 0.07^{\mathrm{b}}$ \\
\hline S5 & $112 \pm 12^{\mathrm{b}}$ & $20 \pm 0.7^{\mathrm{ab}}$ & $0.16 \pm 0.02^{\mathrm{c}}$ & $34 \pm 1.4^{\mathrm{b}}$ & $4 \pm 0.2^{\mathrm{a}}$ & $2.4 \pm 0.3^{\mathrm{e}}$ & $67.8 \pm 0.9^{\mathrm{b}}$ & $3.68 \pm 0.52^{\mathrm{c}}$ & $0.43 \pm 0.04^{\mathrm{b}}$ \\
\hline S6 & $115 \pm 0.7^{\mathrm{ab}}$ & $19.5 \pm 2.1^{\mathrm{b}}$ & $0.3 \pm 0.02^{\mathrm{a}}$ & $41 \pm 1.4^{\mathrm{a}}$ & $4 \pm 0.2^{\mathrm{a}}$ & $2.7 \pm 1.0^{\mathrm{e}}$ & $67.8 \pm 1.0^{\mathrm{b}}$ & $2.57 \pm 0.26^{\mathrm{e}}$ & $0.67 \pm 0.04^{\mathrm{a}}$ \\
\hline S7 & $124 \pm 0.5^{\mathrm{a}}$ & $22.5 \pm 1.4^{\mathrm{a}}$ & $0.08 \pm 0.01^{\mathrm{e}}$ & $30.5 \pm 2.1^{\mathrm{c}}$ & $3.9 \pm 0.5^{\mathrm{ab}}$ & $6.8 \pm 1.4^{\mathrm{c}}$ & $68 \pm 2.6^{\mathrm{ab}}$ & $3 \pm 1.5^{\mathrm{d}}$ & $0.28 \pm 0.02^{\mathrm{c}}$ \\
\hline S8 & $123 \pm 2.1^{\mathrm{a}}$ & $21.2 \pm 1.7^{\mathrm{a}}$ & $0.2 \pm 0.05^{\mathrm{b}}$ & $34 \pm 1.4^{\mathrm{b}}$ & $3.75 \pm 0.7^{b}$ & $13.3 \pm 1.7^{\mathrm{b}}$ & $67.5 \pm 0.6^{\mathrm{b}}$ & $5.17 \pm 0.8^{\mathrm{a}}$ & $0.52 \pm 0.09^{\mathrm{b}}$ \\
\hline S9 & $91.8 \pm 5.2^{\mathrm{d}}$ & $16.5 \pm 0.7$ & $0.08 \pm 0.03^{\mathrm{e}}$ & $31.5 \pm 2.1^{\mathrm{c}}$ & $4.2 \pm 0.4^{\mathrm{a}}$ & $17.1 \pm 2.0^{\mathrm{a}}$ & $68 \pm 0.9^{\mathrm{ab}}$ & $4.2 \pm 2^{\mathrm{bc}}$ & $0.3 \pm 0.05^{\mathrm{c}}$ \\
\hline
\end{tabular}
significant difference $(\mathrm{p}<0.05)$ among means.

Table 1. Physicochemical properties of honey samples collected from Chena district.

$\mathrm{SD}=$ standard deviation; $\mathrm{meq}=$ milli equivalent; $\mathrm{mS}=$ milli Siemens; $\mathrm{HMF}=$ hydroxyl methyl furfural; TRS = total reducing sugar; FA = free acidity; EC = electrical conductivity; $\mathrm{mS} / \mathrm{cm}=$ milli simiens per centimeter; means followed by different superscript letters in a row are significantly different at $p<0.05$. 


\subsubsection{Honey Color (mm Pfund)}

The current result shows that average honey sample color was ranged from $69.2 \pm 0.4$ to $124 \pm 0.5 \mathrm{~mm}$ Pfund scale. The current result revealed that the color of honey samples $\mathrm{S}_{7}$ $(124 \pm 0.5 \mathrm{~mm}$ Pfund $)$ and $\mathrm{S}_{8}(123 \pm 2.1 \mathrm{~mm}$ Pfund $)$ had significantly higher $(\mathrm{p}<0.05)$ than that of other honey samples. According to USDA [14] color standard, the current honey samples color values lie within the quality standard and the current variations in color of honey have no effect on honey quality. The present study is in agreement with the findings by Belay et al. [15] who reported similar result as the color of honey varied according to the melliferous area from different regions of Ethiopia. In addition, Juszczak et al. [16] and Fasasi [17] also stated that variations in the color of honey may probably be due to nectar sources, storage of honey at high relative humidity, storage of honey for long time and exposure to elevated temperatures.

\subsubsection{Moisture Content}

The result revealed that the moisture content of honey samples $S_{7}(22.5 \pm 1.4 \mathrm{~g} / 100 \mathrm{~g})$ and $\mathrm{S}_{8}(21.2 \pm 1.7 \mathrm{~g} / 100 \mathrm{~g})$ followed by $\mathrm{S}_{5}(20 \pm 0.7 \mathrm{~g} / 100 \mathrm{~g}), \mathrm{S}_{2}(19.5 \pm 0.7 \mathrm{~g} / 100 \mathrm{~g})$ and $\mathrm{S}_{6}(19.5 \pm 2.1 \mathrm{~g} / 100 \mathrm{~g})$ (Table 1$)$. The honey samples $\mathrm{S}_{7}(22.5$ $\pm 1.4 \mathrm{~g} / 100 \mathrm{~g})$ and $\mathrm{S}_{8}(21.2 \pm 1.7 \mathrm{~g} / 100 \mathrm{~g})$ had significantly higher $(\mathrm{p}<0.05)$ moisture content than that of other honey samples. The moisture content of the present study is within the country's average (20.6\%) reported by Nuru [18]. The current result is also within the range that the findings of Tessega [19] who reported moisture content of $18.80 \%$. Furthermore, according to these above researchers, the water content is also of great importance because it is considered to be a useful parameter for describing moistness and viscosity of honey. The low moisture content of the honey samples indicates good storage ability of the study area, since high moisture content could lead to fermentation.

\subsubsection{Ash Content}

The result showed that mean ash content of honey samples $\mathrm{S}_{2}(0.3 \pm 0.04 \mathrm{~g} / 100 \mathrm{~g})$ and $\mathrm{S} 6(0.3 \pm 0.02 \mathrm{~g} / 100 \mathrm{~g})$ significantly higher than that of other samples (Table 1). The present study result is in line with the findings of Tewodros [20] who reported $0.23 \%$ ash content of honey samples for Sekota Woreda. But, Baroni et al. [21] and Chua et al. [22] reported lower value for Argentina and Malaysian honeys. The researchers suggested that ash content of honey depends on the material contained in the pollen collected by the bees during foraging on the flora.

\subsection{4. $\mathrm{pH}$}

The honey samples $\mathrm{S}_{9}(4.2 \pm 0.4), \mathrm{S}_{5}(4 \pm 0.2)$ and $\mathrm{S}_{6}(4 \pm$ $0.2)$ had significantly higher $((\mathrm{p}<0.05)$ than $\mathrm{pH}$ value than other honey samples (Table 1). The $\mathrm{pH}$ value of honey samples observed in the present study is similar to those of Tesega [19] who reported $\mathrm{pH}$ ranging from 3.49 to 5.58 for honey from Burie, Ethiopia and Tewodros [23] reported honey $\mathrm{pH}$ ranging from 3.55 to 4.75 for honey from Sekota, Ethiopia. Moreover, the mean $\mathrm{pH}$ value of honey samples of the study area is also in agreement with the findings by Bogdanov [10] who indicated that honey $\mathrm{pH}$ should be between 3.2 and 4.5 .

\subsubsection{Free Acidity}

The mean value of free acidity of honey samples $\mathrm{S}_{1}, \mathrm{~S}_{2}, \mathrm{~S}_{3}$, $\mathrm{S}_{4}, \mathrm{~S}_{5}, \mathrm{~S}_{6}, \mathrm{~S}_{7}, \mathrm{~S}_{8}$ and $\mathrm{S}_{9}$ were $21 \pm 1.4,39 \pm 1.4,28 \pm 2.8,25$ $\pm 2.8,34 \pm 1.4,41 \pm 1.4,30.5 \pm 2,34 \pm 1.4$ and $31.5 \pm 2.1$ $\mathrm{meq} / \mathrm{kg}$, respectively (Table 1$)$. The honey samples $\mathrm{S}_{2}(39 \pm$ $1.4 \mathrm{meq} / \mathrm{kg})$ and $\mathrm{S}_{6}(41 \pm 1.4)$ had significantly higher $((\mathrm{p}<$ $0.05)$ free acidity than other honey samples. Chala et al. [24] reported acidity value of $28.2 \mathrm{meq} \mathrm{acid} / \mathrm{kg}$ in southwestern Ethiopia. It is well known that during fermentation, glucose and fructose are converted into carbon dioxide and alcohol. Alcohol is further hydrolyzed in the presence of oxygen and converted to acetic acid, which contributes to the level of free acidity in honey.

\subsubsection{Hydroxyl Methyl Furfural}

The result showed that the mean value of HMF of honey samples $\mathrm{S}_{1}, \mathrm{~S}_{2}, \mathrm{~S}_{3}, \mathrm{~S}_{4}, \mathrm{~S}_{5}, \mathrm{~S}_{6}, \mathrm{~S}_{7}, \mathrm{~S}_{8}$ and $\mathrm{S}_{9}$ were $2.3 \pm 0.9,2.5$ $\pm 0.6,1.8 \pm 0.2,3.3 \pm 1.6,2.4 \pm 0.3,2.7 \pm 1.0,6.8 \pm 1.4,13.3$ \pm 1.7 and $17.1 \pm 2.0 \mathrm{mg} / \mathrm{kg}$, respectively (Table 1). The honey samples $\mathrm{S}_{9}(17.1 \pm 2.0 \mathrm{mg} / \mathrm{kg})$ followed by $\mathrm{S}_{8}(13.3 \pm$ $1.7 \mathrm{mg} / \mathrm{kg}$ ) had significantly higher $(\mathrm{p}<0.05) \mathrm{HMF}$ value than other honey samples. HMF content is widely recognized as a parameter of honey samples freshness, because it is absent in fresh honeys and tends to increase during processing and/or aging of the product. The present result is in agreement with the findings of Tessega [19] and Chala [25] but lower than national average $32.4 \mathrm{mg} / \mathrm{kg}$ as reported by (Nuru, 1999) that established as mean result of Ethiopian honey.

\subsubsection{Total Reducing Sugars}

The result showed that the mean value of total reducing sugar of honey samples $\mathrm{S}_{1}, \mathrm{~S}_{2}, \mathrm{~S}_{3}, \mathrm{~S}_{4}, \mathrm{~S}_{5}, \mathrm{~S}_{6}, \mathrm{~S}_{7}, \mathrm{~S}_{8}$ and $\mathrm{S}_{9}$ were $69.7 \pm 1.0,68 \pm 0.6,69 \pm 1.4,70.2 \pm 1.0,67.8 \pm 0.9$, $67.8 \pm 1.0,68 \pm 2.6,67.5 \pm 0.6$ and $68 \pm 0.9 \mathrm{~g} / 100 \mathrm{~g}$, respectively (Table 1$)$. The honey samples $\mathrm{S}_{4}(70.2 \pm 1.0$ $\mathrm{g} / 100 \mathrm{~g})$ followed by $\mathrm{S}_{1}(69.7 \pm 1.0 \mathrm{~g} / 100 \mathrm{~g})$ and $\mathrm{S}_{3}(69 \pm 1.4$ $\mathrm{g} / 100 \mathrm{~g})$ had significantly higher $(\mathrm{p}<0.05)$ total reducing sugar content than other honey samples. The current result is in line with Awraris et al. [26] who reported the total reducing sugar value ranging from 64.78 to $69.27 \%$ in Ethiopian honey analyzed from Southwestern Ethiopia. In addition, similar findings were reported by Tewodros [23] for honey samples collected from Sekota district.

\subsubsection{Sucrose Content}

The result showed that the mean value of sucrose content of honey samples $\mathrm{S}_{1}, \mathrm{~S}_{2}, \mathrm{~S}_{3}, \mathrm{~S}_{4}, \mathrm{~S}_{5}, \mathrm{~S}_{6}, \mathrm{~S}_{7}, \mathrm{~S}_{8}$ and $\mathrm{S}_{9}$ were 3.1 $\pm 1.6,4.73 \pm 0.8,2.84 \pm 0.8,3.2 \pm 0.45,3.68 \pm 0.52,2.57 \pm$ $0.26,3 \pm 1.5,5.17 \pm 0.8$ and $4.2 \pm 2 \mathrm{~g} / 100 \mathrm{~g}$, respectively (Table 1). The honey samples $\mathrm{S}_{8}(5.17 \pm 0.8 \mathrm{~g} / 100 \mathrm{~g})$ followed by $\mathrm{S}_{2}(4.73 \pm 0.8 \mathrm{~g} / 100 \mathrm{~g})$ and $\mathrm{S}_{9}(4.2 \pm 2 \mathrm{~g} / 100 \mathrm{~g})$ had significantly higher $(\mathrm{p}<0.05)$ sucrose content than other 
honey samples. Similarly, Tewodros et al. [23] reported the sucrose level of honey ranged between 1.0 to $5.2 \%$ and Awraris et al. (2014) that ranged between 1.68 to $6.37 \%$ in previous studies of Ethiopian honey. According to the findings of Bogdanov [10], sucrose content in the honey sample is a significant criterion to determine the honey purity. This is because the sucrose present in natural or pure honey is little because of the activity of invertase enzyme present in honey. These enzymes are responsible for the breakdown of sucrose. Thus, the content of sucrose in pure honey is low. Overheating of the honey sample might denature invertase, stopping the enzyme activity that breaks down the sucrose into glucose and fructose. Thus, sucrose level remains high in the heated honey.

\subsubsection{Electrical Conductivity}

The result showed that the mean value of sucrose content of honey samples $\mathrm{S}_{1}, \mathrm{~S}_{2}, \mathrm{~S}_{3}, \mathrm{~S}_{4}, \mathrm{~S}_{5}, \mathrm{~S}_{6}, \mathrm{~S}_{7}, \mathrm{~S}_{8}$ and $\mathrm{S}_{9}$ were $0.48 \pm 0.04,0.68 \pm 0.08,0.5 \pm 0.08,0.4 \pm 0.07,0.43 \pm 0.04$, $0.67 \pm 0.04,0.28 \pm 0.02,0.52 \pm 0.09$ and $0.3 \pm 0.05 \mathrm{mS} / \mathrm{cm}$, respectively (Table 1). The honey samples $\mathrm{S}_{2}(0.68 \pm 0.08$ $\mathrm{mS} / \mathrm{cm})$ and $\mathrm{S}_{6}(0.67 \pm 0.04 \mathrm{mS} / \mathrm{cm})$ followed by $\mathrm{S}_{3}(0.5 \pm$ $0.08)$ and $\mathrm{S}_{8}(0.52 \pm 0.09 \mathrm{mS} / \mathrm{cm})$ had significantly higher $(\mathrm{p}$ $<0.05$ ) electrical conductivity than other honey samples. The result of the present study is in agreement with the findings of Tewodros et al. [20] who reported 0.17 to $1.35 \mathrm{mS} / \mathrm{cm}$ in Ethiopian honey. Similarly, the present result is also in agreement with the electrical conductivity value reported by Belay et al. [15] for the honey produced from different floral sources at Ethiopia with mean $0.58 \mathrm{mS} / \mathrm{cm}$.

\section{Conclusions and Recommendations}

The study result revealed that $\mathrm{S}_{2}$ and $\mathrm{S}_{6}$ honey samples contained the highest ash $(0.3 \pm 0.02$ and $0.3 \pm 0.04 \mathrm{~g} / 100 \mathrm{~g}$, respectively), free acidity $(39 \pm 1.4$ and $41 \pm 1.4 \mathrm{meq} / \mathrm{kg}$, respectively) and electrical conductivity $(0.68 \pm 0.08$ and $0.67 \pm 0.04 \mathrm{mS} / \mathrm{cm}$, respectively) than other honey samples. The honey samples $\mathrm{S}_{7}$ and $\mathrm{S}_{8}$ had highest moisture content $(22.5 \pm 1.4$ and $21.2 \pm 1.7 \mathrm{~g} / 100 \mathrm{~g}$, respectively) and honey color (124 \pm 0.5 and $123 \pm 2.1 \mathrm{~mm}$ Pfund scale, respectively) than other honey samples. The honey sample $\mathrm{S}_{5}(4 \pm 0.2), \mathrm{S}_{6}$ $(4 \pm 0.2)$, and $\mathrm{S}_{9}(4.2 \pm 0.4)$ had highest $\mathrm{pH}$ value. In addition, the result showed that $\mathrm{S}_{9}$ contained highest $\mathrm{HMF}$ content $(17.1 \pm 2 \mathrm{mg} / \mathrm{kg})$. Furthermore, honey sample $\mathrm{S}_{1}$ $(69.7 \pm 1 \mathrm{~g} / 100 \mathrm{~g})$ and $\mathrm{S}_{4}(70.2 \pm 1)$ contained the highest total reducing sugar. Finally, the result showed that honey sample $\mathrm{S}_{8}$ had highest sucrose content $(5.17 \pm 0.8 \mathrm{~g} / 100 \mathrm{~g})$. Results obtained in this study, indicated that tested honey samples produced in Chena district are good for national as well as international market. More research should be conducted on the storage effect of honey to evaluate its safety for human consumption.

\section{Conflict of Interest}

The authors declare that they have no competing interests.

\section{Acknowledgements}

We would like to thank Southern Agricultural Research Institute Ethiopia for their logistic support; Hawassa University, School of Human Nutrition, Food Science and Technology for laboratory service.

\section{References}

[1] AOAC. 2000. Official method of analysis of the association of the analytical Chemists.

[2] Awraris Getachew Shenkute, Yemisrach Getachew, Assefa Dejen, NuruAdgaba, Ganga Gebeyehu and Bonga, W. A. 2012. Honey production systems (Apismellifera L.) in Kafa, Sheka and Bench-Maji zones of Ethiopia. Journal of Agricultural Extension and Rural Development Vol. 4 (19), pp. 528-541.

[3] Awraris Getachew Shenkutie, Hailemariam Gizaw, Dejen Aseffa. 2014. Physico-chemical Properties of Honey Produced in Masha, Gesha, and Sheko Districts in South-western Ethiopia. Current Research in Agricultural Sciences 1, $110-$ 116.

[4] Baroni, M. V., Arrua, C., Nores, M. L., P. Fayé, M. P. Díaz, G. A., Chiabrando, D. A., Wunderlin. 2009. Composition of honey from Córdoba (Argentina): assessment of North/South provenance by chemometrics. Food Chemistry 114, 727-733.

[5] Belay Abera, Gulelat Desse Haki, Marc Birringer, Hannelore Borck, Young- Chul Lee, Chang-Won Cho, Kyung-Tack Kim, Bikila Bayissa, Kaleab Baye \& Samuel Melaku. 2017. Sugar profile and physicochemical properties of Ethiopian monofloral honey. International Journal of Food Properties 20 (11), 2855-2866.

[6] Bogdanov, S. 2009. Physical properties of honey. In: Book of Honey, Chapter 4. Bee Product Science. www.beehexagon.net.

[7] Buba, F., Gidado, A., Shugaba, A. 2013. Analysis of biochemical composition of honey samples from North-East Nigeria. J. Biochemistry Analog 2, 139.

[8] Cantarelli, MA., Pellerano, RG., Marchevsky, EJ., Camina. 2008. Quality of honey from Argentina: study of chemical composition and trace elements. The Journal of the Argentine Chemical Society 96, 33-41.

[9] Chala Kinat. 2010. Honey Production, Marketing System and Quality Assessment in Gomma Woreda, South Western Ethiopia. Livestock research for rural development 15 (4), 123- 125 .

[10] Chala Kinat, Taye Toleramariam and Kebede Debele. 2011. Quality evaluation of honey produced in Gomma Woreda of South Western Ethiopia, Jimma University, College of Agriculture and Veterinary Medicine. Livestock research for rural development 23 (9), 341 - 349.

[11] Chua, L. S., N. L. Abdul-Rahaman, Sarmidi, M. R., R. Aziz. 2012. Multi-elemental composition and physical properties of honey samples from Malaysia. Food Chemistry 135, 880887.

[12] Codex Alimentarius. 2001. Revised Codex Standard for Honey, Codex STAN 12-1981, Revision 1 (1987), Revision 2. 
[13] Council Directive of the European Union. 2002. Council Directive 2001/110/ EC 20 December 2001 relating to honey. Official Journal of the European Communities 10, 47-52.

[14] Desalegn Paulos. 2011. Ethiopian Honey: Accessing International Markets with Inclusive Business and Sector Development, SNV Ethiopia. Available at: $<$ file:///C:/Users/gebruiker/Downloads/7._soc_ethiopia_honey $\% 20(23)$.pdf $>$ [accessed on 12/07/2018].

[15] FAO. 2010. FAOSTAT database on Agriculture and Nutrition. Food and Agricultural Organization of the United Nations, Rome, Italy. Available at: http://faostat.fao.org/site/569, accessed 12th Aug. 2012.

[16] Fasasi, K. A. 2012. Physicochemical Attributes of Nigerian Natural Honey form Honeybees (Apis medllifera adansonii) (Hymenoptera: Apidae) and its Shelf Life in Storage at Room Temperature. Pakistan Journal of Biological Sciences 15 (21), $1027-1033$.

[17] Gidey Yirga and Teferi Mekonen. 2010. Participatory Technology and Constraints Assessment to Improve the Livelihood of Beekeepers in Tigray Region, northern Ethiopia. Momona Ethiopian Journal of Science 2 (1): 76-92.

[18] Juszczak, L., Socha, J., Roznowski, Fortuna, T., Nalepka, K. 2009. Physicochemical properties and quality parameters of herb honeys. Journal of Food Chemistry 113, 538-542.

[19] Lane, J. H. and Eynon, L. 1923. Determination of reducing sugar by means of Fehling's solution with methylene blue as internal indicator. Journal of Indian Chemical Society.
[20] Lazaridou, A., Biliaderis, C G., Bacandritsos, N., Sabatini, AG. 2004. Composition, thermal and rheological behavior of selected Greek honeys. Journal of Food Engineering 64, 9-21.

[21] Nuru Adgaba. 1999. Quality state and grading of Ethiopian honey. pp. 74-82. Proceedings of the first National Conference of Ethiopian Beekeepers Association (EBA), June 7-8, Addis Ababa, Ethiopia.

[22] Nuru Adgaba, Adimasu Addi, and Dereje Woltedji. 2001. Pollen Spectrum of Honeys and Honey Bee floral Calendar of West Shoa. Third National Annual Conference of the Ethiopian Beekeepers Association, Addis Ababa.

[23] Tessega Belie. 2009. Honeybee Production and Marketing Systems, Constraints and Opportunities in Burie District of Amahara Region, Ethiopia. M.Sc. Thesis.

[24] Tewodros Alemu. 2010. Assessment of Honeybee Production Practices and Honey Quality in Sekota Woreda of Waghimra Zone, Ethiopia. MSc Thesis Presented to the School of Graduate Studies of Haramaya University. Pp. 122.

[25] Tewodros Alemu, Eyassu, S., Amsalu Bezabih. 2013. Physicochemical Properties of Honey Produced in Sekota District, Northern Ethiopia. International Food Research Journal 20, 3061-3067.

[26] USAID (United States Agency for International Development). 2012. Cost-Benefit Analysis of the Honey Value Chain in Ethiopia, Graduation With Resilience to Achieve Sustainable Development - Grad Project Final Report. 